Tomasz Biernat* Toruń; Leon Dyczewski* Lublin;

Pawet Sobierajski* Toruń; Justyna Szulich-Kałuża* Lublin

\title{
Wyobrażenia młodzieży w Polsce o małżeństwie
}

\section{Charakterystyka próby badawczej}

Niniejsze badania zostały przeprowadzone w czterech województwach: mazowieckim, pomorskim, lubelskim oraz kujawsko-pomorskim. Miały one charakter ankiety audytoryjnej i były realizowane w okresie od listopada 2004 roku do stycznia 2005. Objęły one swoim zasięgiem młodzież ${ }^{1}$ uczącą się lub studiującą z celowo dobranych miejscowości o różnej wielkości (duże miasta: Warszawa, Gdańsk, Bydgoszcz, Lublin, Toruń, średnie miasta: Płock, Inowrocław, Chełm, Tomaszów Lubelski, Zamość, małe miasta: Sochaczew, Chojnice, Chełmża oraz wsie: Adamów, Gronowo). Ankieta była przeprowadzona ze studentami III i IV roku studiów z kierunków humanistycznych i niehumanistycznych oraz z uczniami ostatnich klas szkół średnich ogólnokształcących i zawodowych. W skład badanej grupy weszła też pewna liczba osób pracujących i bezrobotnych z Lublina, z którymi przeprowadzono wywiad w oparciu o ten sam kwestionariusz. Respondentami była młodzież w wieku od 18 do 26 lat. Materiał badawczy obejmuje 2351 poprawnie wypełnionych ankiet ${ }^{2}$.

* Autorzy reprezentują dwa ośrodki naukowe: Instytut Pedagogiki UMK w Toruniu (dr T. Biernat, dr P. Sobierajski) oraz Instytut Socjologii KUL w Lublinie (prof. dr hab. L. Dyczewski, dr J. Szulich-Kałuża).

${ }^{1}$ Szczegółowa charakterystyka badanej grupy została przedstawiona w poprzednim numerze „Peadagogia Christiana” w artykule tych samych autorów pt. Wyobrażenia młodzieży w Polsce o rodzinie.

${ }^{2}$ Badania zostały zrealizowane z funduszy Komitetu Badań Naukowych. 
Tabela 1. Liczba osób przebadanych w poszczególnych środowiskach $(\mathrm{N}=2351)$

\begin{tabular}{|c|c|c|c|}
\hline $\begin{array}{c}\text { Miasta duże, } \\
\text { ponad 100 tys. } \\
\text { mieszkańców }\end{array}$ & $\begin{array}{c}\text { Miasta średnie, } \\
\text { od 50 do 100 tys. } \\
\text { mieszkańców }\end{array}$ & $\begin{array}{c}\text { Miasta małe, } \\
\text { mniej niż 50 tys. } \\
\text { mieszkańców }\end{array}$ & $\begin{array}{c}\text { Środowisko } \\
\text { wiejskie }\end{array}$ \\
\hline $1493(63,5 \%)$ & $431(18,3 \%)$ & $280(11,9 \%)$ & $147(6,3 \%)$ \\
\hline
\end{tabular}

Wyniki uzyskane w poszczególnych województwach nie różniły się w sposób istotny statystycznie w badanych kwestiach, $\mathrm{z}$ tego względu poniższe analizy mają charakter wspólny dla badanych województw. W próbie badawczej znalazło się 52,4\% kobiet i 47,6\% mężczyzn. Zdecydowaną większość stanowiły osoby stanu wolnego - 94,7\% (w związku małżeńskim było już 4\% respondentów, z dziećmi - 3,2\%). Respondenci najczęściej wzrastali w rodzinach pełnych z matką i ojcem (87,9\%). Część z nich żyła w rodzinach niepełnych: z samotną matką (7,7\%), samotnym ojcem $(0,6 \%)$ oraz niewielki odsetek w rodzinach zrekonstruowanych częściej z ojczymem (2,8\%) niż z macochą (0,3\%). Tylko kilka badanych osób funkcjonowało w innych formach życia rodzinnego. W większości przypadków rodzice respondentów żyją razem i mają ślub (79,7\%).

Ponad połowa badanych $(59,5 \%)$ ma średnie wykształcenie (z matura); prawie co druga osoba studiuje (49,3\%). Pozostali respondenci uczą się w szkole policealnej/pomaturalnej (9,8\%) lub zawodowej (6,3\%). Tylko 2,3\% młodzieży pracuje zawodowo (bezrobotni - 3,0\%).

Zdecydowana większość badanych określa siebie jako osobę religijną, częściej niż co trzecia osoba uważa się nawet za bardzo religijną. Respondenci przeważnie należą do Kościoła katolickiego $(93,4 \%)$, nieliczni do Kościoła prawosławnego lub ewangelickiego $(0,2 \%)$, do innych grup religijnych $(1,3 \%)$, a 5,0\% (118 osób) nie identyfikuje się z żadną grupą religijną.

\section{Małżeństwo w opinii młodzieży}

Małżeństwo jest społecznie zaakceptowaną formą współżycia pary osób i najbardziej akceptowanym sposobem konstytuowania rodziny. Stanowi formę stabilizacji związku partnerskiego, zabezpieczając prawne interesy zarówno samych małżonków, jak i ich dzieci. Jest stale pożądanym i oczekiwanym związkiem na poziomie jednostki i w wymiarze społecznym. Małżeństwo, obok rodziny, znajduje się u szczytu wartości pożądanych przez młodzież. Powszechnie zauważa się jednak, że instytucja ta staje się coraz bardziej krucha i niestabilna zwłaszcza w krajach wysoko rozwiniętych (Giza-Poleszczuk 2002: 236). 
Tabela 2. Opinie o małżeństwie a płeć (w \%, N=2341)

\begin{tabular}{|l|c|c|c|}
\hline \multirow{2}{*}{\multicolumn{1}{|c|}{ Kategoria odpowiedzi }} & \multicolumn{2}{|c|}{ Płeć } & \multirow{2}{*}{ Ogółem } \\
\cline { 2 - 3 } & K & M & 7,1 \\
\hline Jest przestarzałą instytucją & 6,4 & 7,9 & 75,1 \\
\hline Ma i będzie mieć duże znaczenie & 76,5 & 73,5 & 17,8 \\
\hline Nie mam zdania & 17,1 & 18,6 & \multirow{2}{*}{} \\
\hline
\end{tabular}

Trzy czwarte badanych $(75,1 \%)$ uważa, że małżeństwo ma dziś i będzie mieć w przyszłości duże znaczenie, $17,8 \%$ nie ma na ten temat zdania, a 7,1\% uważa małżeństwo za przestarzałą instytucję (tab. 2). Analizy statystyczne pokazują wiele istotnych zależności. Dla młodych osób uważających, że małżeństwo ma i będzie mieć znaczenie w przyszłości bardzo ważne jest „założyć własną rodzinę” $\left(\chi^{2}=194,79 ; \mathrm{df}=10 ; \mathrm{p}=0,00 ; \mathrm{C}=0,277\right)$, ,żyć zgodnie $\mathrm{z}$ religią" $\left(\chi^{2}=226,43 ; \mathrm{df}=10\right.$; $\mathrm{p}=0,00 ; \mathrm{C}=0,297)$ oraz ,wspólna chęć posiadania dzieci” $\left(\chi^{2}=132,6 ; \mathrm{df}=10 ; \mathrm{p}=0,00\right.$; $\mathrm{C}=0,232) \mathrm{i}$,wspólne przekonania religijne" $\left(\chi^{2}=173,79 ; \mathrm{df}=10 ; \mathrm{p}=0,00 ; \mathrm{C}=0,263\right)$. Osoby, które wysoko cenią małżeństwo na pytanie „Co będzie dla nich ważne za 25 lat?” najczęściej wybierają odpowiedzi: „dobrze rozumiem się z dziećmi” $(61,05)$, „mam dzieci” (54,4\%), ,jestem żonaty/jestem mężatką” (53,2\%). Dodajmy, że zdecydowana większość respondentów $(84,7 \%)$ uważa, iż ślub kościelny jest ważniejszy niż cywilny, przy czym 49,6\% deklaruje, że ślub kościelny jest ważniejszy ze względów religijnych, natomiast $35,1 \%$ przypisuje rangę pierwszeństwa ślubowi kościelnemu i jednocześnie swoją religijność ocenia jako słabszą.

Obecnie sprawą dyskusyjną stało się przyjmowanie nazwiska przez współmałżonków - pokazują to też nasze wyniki badań. Respondenci uważają, że każdy z małżonków sam powinien decydować o swoim nazwisku (45,8\%). Niewiele mniej opowiedziało się za tym, aby żona przyjęła nazwisko męża (38,4\%), a nieliczni (10,2\%) uważaja, że kobieta powinna mieć podwójne nazwisko: własne i męża. Płeć statystycznie istotnie różnicuje wybór nazwiska po ślubie - większość mężczyzn $(60,7 \%)$ chce, aby żona przyjęła nazwisko męża, a ponad połowa kobiet $(55,4 \%)$ postuluje, aby każde z małżonków mogło decydować o swoim nazwisku $\left(\chi^{2}=149,73\right.$; $\mathrm{df}=6 ; \mathrm{p}=0,00 ; \mathrm{C}=0,245)$.

Szczególnie interesujące wydają się opinie młodzieży na temat: co czyni małżeństwo udanym? W ich świetle wyłaniają się cztery podstawowe wartości i cechy życia małżeńsko-rodzinnego: wzajemny szacunek i tolerancja, wierność emocjonalna, wierność seksualna oraz umiejętność wzajemnego przebaczania. Najmniej ważne według młodzieży są: zgodność poglądów politycznych, takie samo pochodzenie społeczne i wspólne przekonania religijne (tab. 3). Warto zauważyć, że płeć różnicuje ocenę wierności seksualnej (jako wartości ważnej w małżeństwie) - bardziej cenią ją kobiety $(56,9 \%)$ niż mężczyźni $(49,1 \%)$. 


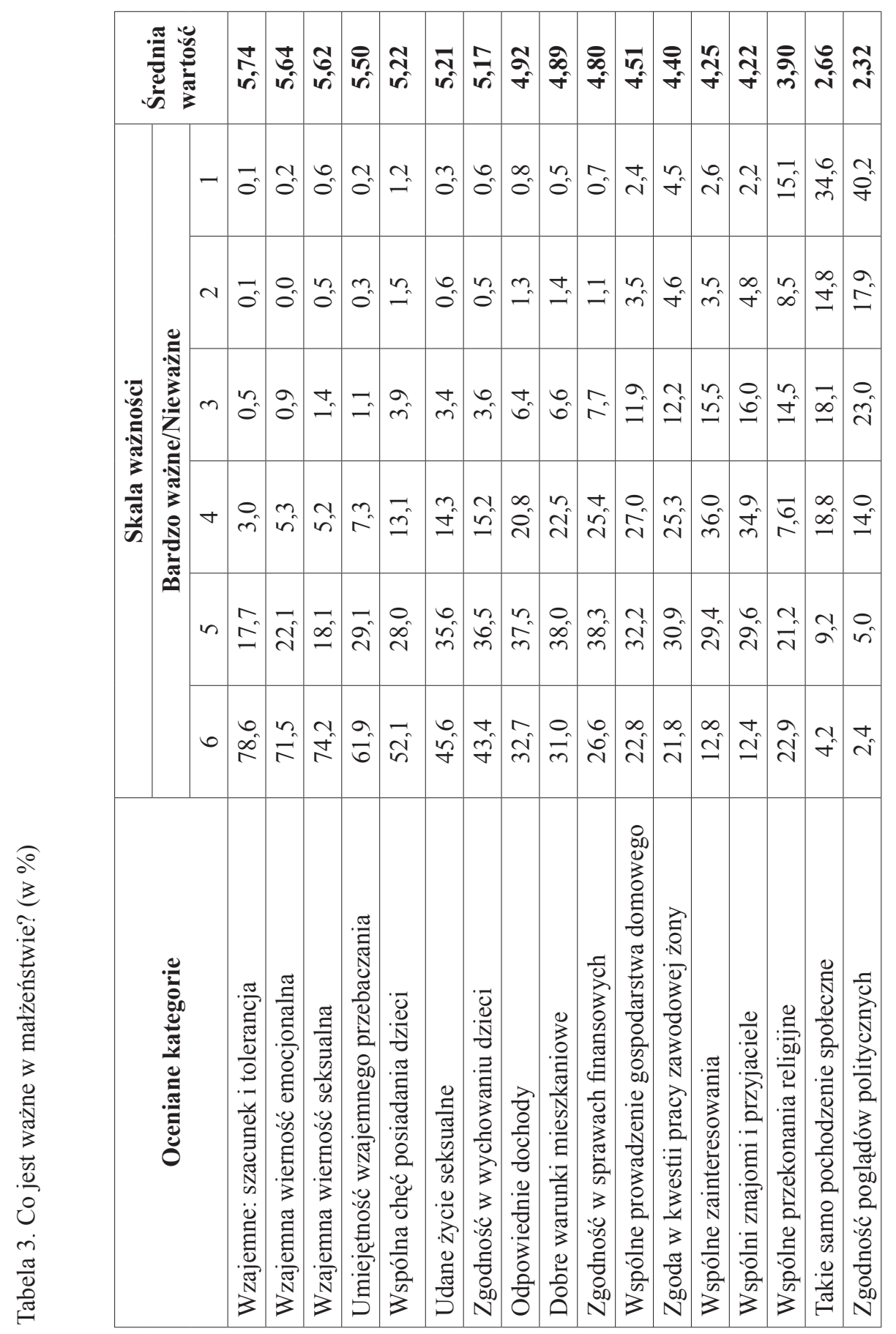


Wypowiedzi badanych potwierdzają upowszechnienie się modelu małżeństwa opartego na wzajemnym uczuciu. Wśród powodów skłaniających do zawarcia małżeństwa najczęściej wskazywali oni na: miłość do partnera - 68,9\%, chęć wspólnego posiadania dzieci - 52,1\%, uzyskanie poczucia bezpieczeństwa - 34,6\%. Niewielu respondentów (109 osób - 4,6\% ogółu) nie chce w ogóle zawierać ślubu. Swą postawę thumaczą najczęściej tym, że ślub nie jest gwarantem trwałości związku $(60,6 \%)$, iż niesie z sobą różnego rodzaju ograniczenia (36,7\%), że trudno jest przeprowadzić rozwód (27,5\%), że państwa nie powinno obchodzić prywatne życie obywateli $(25,7 \%)$.

\subsection{Zwiqzki partnerskie w opinii mlodzieży}

Do zjawisk związanych z życiem rodzinnym/rodziną należą dzisiaj kohabitacja i związki LAT (,living apart together”- życie razem, ale osobno), czyli związki nieformalne. Wprawdzie istniały one we wszystkich epokach i kulturach, ale dopiero w ostatnich latach wzbudziły zainteresowanie badaczy z dziedziny nauk społecznych. W Polsce związki nieformalne, określane najczęściej konkubinatem, są nadal stosunkowo rzadkim zjawiskiem, ale upowszechniają się we wszystkich grupach wiekowych i kategoriach społecznych (Kwak 2005: 11; Slany 2002: 18). Po raz pierwszy odnotował je Spis Powszechny z roku 2002. Osoby, które żyją w takich związkach, nie są dzisiaj społecznie dyskryminowane, jak to bywało dawniej. Interesowało nas jak tego rodzaju związki ocenia młodzież.

Ogromna większość respondentów unika zdecydowanej odpowiedzi i stwierdza, że jest to dla niej obojętne (71,1\%), co dziesiąty uważa, że jest to dobre rozwiązanie (10,6\%), a prawie co piąty jest temu przeciwny (18,3\%). Okazuje się, że młodzież zdecydowanie jest za normalizacją życia rodzinnego przez ślub.

Próbowaliśmy też zebrać informacje na temat, co jest atrakcyjne i ważne według młodych ludzi w związku nieformalnym. Podobnie, jak w przypadku udanego małżeństwa, młodzież najczęściej wymienia: wzajemny szacunek i tolerancję; wzajemną wierność seksualną i emocjonalną; zdolność do przebaczania. Najmniej ważne okazały się wspólne przekonania religijne, takie samo pochodzenie społeczne i zgodność w kwestiach politycznych. Dane te potwierdzają tezę, że młodzież zarówno wobec małżeństwa, jak i wobec związków nieformalnych, ma te same lub bardzo zbliżone oczekiwania i jednakowo wartościuje uwarunkowania udanego małżeństwa i udanego związku nieformalnego.

Jak wyobraża sobie młodzież późniejsze życie biorąc pod uwagę życie w związku partnerskim? Z zaproponowanych możliwości młodzież najczęściej wybierała dwie formy. Najpierw chce żyć i mieszkać z partnerem lub partnerką, aby się sprawdzić przed ślubem, a potem, gdy próba powiedzie się, wziąć ślub $(45,2 \%)$. Druga forma, tradycyjna, polega na wspólnym życiu jedynie w sformalizowanym związku małżeńskim (37,8\%). Pierwszą formę częściej wybierają ci badani, którzy mają obojętny stosunek wobec par żyjących bez ślubu $\left(\chi^{2}=552,11 ; \mathrm{df}=10 ; \mathrm{p}=0,00 ; \mathrm{C}=0,44\right)$ 
oraz młodzież poniżej 20 roku życia $\left(\chi^{2}=95,25 ; \mathrm{df}=5 ; \mathrm{p}=0,00 ; \mathrm{C}=0,199\right)$. Z kolei życie tylko w związku małżeńskim częściej wybierają ci, którzy wysoko oceniają wartość małżeństwa $\left(\chi^{2}=330,65 ; \mathrm{df}=10 ; \mathrm{p}=0,00 ; \mathrm{C}=0,355\right) \mathrm{i}$, ,życie zgodne $\mathrm{z}$ zasadami religijnymi" $\left(\chi^{2}=421,62 ; \mathrm{df}=25 ; \mathrm{p}=0,00 ; \mathrm{C}=0,394\right)$. Słabsza zależność (chociaż statystycznie istotna) występuje między płcią a preferowanymi wyborami - więcej kobiet (57,4\%) niż mężczyzn (42,6\%) uważa, że wspólne życie może mieć miejsce tylko w związku małżeńskim $\left(\chi^{2}=45,72 ; \mathrm{df}=5 ; \mathrm{p}=0,00 ; \mathrm{C}=0,139\right)$.

Pomimo dużej propagandy prowadzonej ostatnio przez media na rzecz zrównania par bez ślubu z małżeństwami, wśród młodzieży dominuje postawa przeciwna temu rozwiązaniu (42,3\%). Za zrównaniem w prawie obu tych form jest co trzeci respondent (36,2\%), a 21,5\% nie wie, co na ten temat sądzić (tab. 4).

Tabela 4. Prawne zrównanie pary bez ślubu z małżeństwami a płeć (w \%; N=2345)

\begin{tabular}{|c|c|c|c|}
\hline \multirow{2}{*}{$\begin{array}{c}\text { Kategorie } \\
\text { odpowiedzi }\end{array}$} & \multicolumn{2}{|c|}{ Pleć } & \multirow{2}{*}{ Ogólem } \\
\cline { 2 - 3 } & K & M & 36,2 \\
\hline Jestem za & 37,0 & 35,2 & 42,3 \\
\hline Jestem przeciw & 41,6 & 43,0 & 21,5 \\
\hline Nie wiem & 21,4 & 21,8 & \\
\hline
\end{tabular}

Przeciwko zrównaniu prawnemu związków nieformalnych z małżeństwami najczęściej są te osoby, które wybierają wartości rodzinne i religijne (48,9\%), uważają, że życie rodzinne ma coraz większe znaczenie $(47,4 \%)$, są przeciwnikami życia par bez ślub $(75,1 \%)$ i zwolennikami ślubu kościelnego (53,3\%). Dołączają do nich respondenci, którzy opowiadają się przeciwko rozwodom $(59,2 \%)$ i małżeństwom homoseksualistów oraz ci, którzy wysoko oceniają swoje relacje z ojcem i związek swoich rodziców.

Badana młodzież wyraża negatywne stanowisko wobec legalizacji par homoseksualnych. Zdecydowana większość młodzieży jest za tym $(63,4 \%)$, żeby pary homoseksualne nie mogły brać ślubu, czyli nie mogły tworzyć małżeństw i rodzin. Co czwarty respondent $(22,8 \%)$ uważa za słuszne, żeby pary homoseksualne mogły brać ślub, a bardzo nieliczni $(3,8 \%)$ - żeby mogły brać ślub i posiadać prawo do adopcji $(3,8 \%)$. 
Tabela 5: Prawo par homoseksualnych do zawarcia związku małżeńskiego a płeć (w \%, N=2342)

\begin{tabular}{|l|c|c|c|}
\hline \multirow{2}{*}{ Kategorie odpowiedzi } & \multicolumn{2}{|c|}{ Pleć } & \multirow{2}{*}{ Ogółem } \\
\cline { 2 - 3 } & K & M & \multirow{2}{*}{22,8} \\
\hline $\begin{array}{l}\text { Jestem za tym, aby pary } \\
\text { homoseksualne mogły brać ślub }\end{array}$ & 27,8 & 17,3 & \multirow{2}{*}{3,8} \\
\hline $\begin{array}{l}\text { Jestem za tym, aby pary } \\
\text { homoseksualne mogły brać ślub } \\
\text { i mieć prawo do adopcji }\end{array}$ & 5,1 & 2,3 & 63,4 \\
\hline $\begin{array}{l}\text { Jestem przeciw, aby pary } \\
\text { homoseksualne mogły brać ślub }\end{array}$ & 56,8 & 70,6 & 10,1 \\
\hline Nie wiem & 10,4 & 9,8 & \multirow{2}{*}{} \\
\hline
\end{tabular}

Przeciwnicy zawierania małżeństw przez pary homoseksualne, częściej odrzucają życie bez ślubu (85,6\%), uważają, że małżeństwo ma dziś i będzie miało w przyszłości duże znaczenie (68,3\%), przekonanych, że rodzina/życie rodzinne ma coraz większe znaczenie $(70,3 \%)$, preferujących ślub kościelny, $(75,1 \%)$ oraz przeciwników rozwodów $(80,1 \%)$.

Widać tu jeszcze jedną prawidłowość: im wyżej młodzież ocenia swoje relacje z matką i ojcem, własną religijność i związek rodziców, tym częściej neguje śluby dla homoseksualistów. Również więcej mężczyzn (70,6\%) niż kobiet $(56,8 \%)$ jest przeciwnych takiemu rozwiązaniu $\left(\chi^{2}=57,61 ; \mathrm{df}=3 ; \mathrm{p}=0,00 ; \mathrm{C}=0,157\right)$.

\subsection{Rozwody w opinii młodzieży}

We współczesnym świecie rozwody są częstym zjawiskiem. W polskim prawodawstwie wprowadzono je w 1946 roku, a od 1999 roku istnieje możliwość separacji. W porównaniu z innymi krajami europejskimi w Polsce występują one rzadziej. Respondenci w zdecydowanej większości (76,2\%) opowiadają się za dopuszczalnością rozwodów, jeśli istnieją ku temu poważne powody (tab. 6).

Tabela 6. Stosunek młodzieży do rozwodu (w \%, N=2349)

\begin{tabular}{|l|c|c|c|}
\hline \multirow{2}{*}{ Kategoria odpowiedzi } & \multicolumn{2}{c|}{ Płeć } & \multirow{2}{*}{ Ogółem } \\
\cline { 2 - 3 } & K & M & gom \\
\hline Jestem zasadniczo przeciw rozwodom & 15,0 & 23,4 & 19,1 \\
\hline Jestem za rozwodem, jeśli istnieją poważne powody & 82,1 & 69,9 & 76,2 \\
\hline Nie mam zdania & 2,9 & 6,7 & 4,7 \\
\hline
\end{tabular}


Stanowisko młodzieży wobec rozwodów determinują: religijność $\left(\chi^{2}=141,15\right.$; $\mathrm{df}=12 ; \mathrm{p}=0,00 ; \mathrm{C}=0,238$ ), stosunek do aborcji (dopuszczenie aborcji w wyjątkowych sytuacjach $)\left(\chi^{2}=106,49 ; \mathrm{df}=6 ; \mathrm{p}=0,00 ; \mathrm{C}=0,209\right)$, brak przyzwolenia na prawo zawierania ślubów przez pary homoseksualne $\left(\chi^{2}=281,40 ; \mathrm{df}=8 ; \mathrm{p}=0,00 ; \mathrm{C}=0,327\right)$, brak przyzwolenia na zrównanie praw związków nieformalnych $\mathrm{z}$ małżeństwem $\left(\chi^{2}=114,78 ; \mathrm{df}=4 ; \mathrm{p}=0,00 ; \mathrm{C}=0,216\right)$, preferowanie zasady ,żyć zgodne $\mathrm{z}$ normami religijnymi" $\left(\chi^{2}=24,42 ; \mathrm{df}=4 ; \mathrm{p}=0,00 ; \mathrm{C}=0,240\right)$, uznanie wartości ślubu kościelnego $\left(\chi^{2}=114,17 ; \mathrm{df}=6 ; \mathrm{p}=0,00 ; \mathrm{C}=0,216\right)$, a także obojętny stosunek do par żyjących bez ślubu $\left(\chi^{2}=186,42 ; \mathrm{df}=4 ; \mathrm{p}=0,00 ; \mathrm{C}=0,271\right)$.

Najczęściej wskazywanymi przez młodzież powodami do rozwodu są (tab. 7): przemoc w małżeństwie lub w rodzinie $(90,2 \%)$, niewierność $(54,7 \%)$, nieustające kłótnie lub problemy, które nie dają się rozwiązać $(35,6 \%)$, uzależnienie partnera/ki od alkoholu lub narkotyków $(32,1 \%)$.

Tabela 7. Powody do rozwodów a płeć (w \%, N=2345)

\begin{tabular}{|l|c|c|c|c|c|}
\hline \multirow{2}{*}{\multicolumn{1}{|c|}{ Powody do rozwodu }} & \multicolumn{4}{|c|}{ Pleć } & \multirow{2}{*}{ Ogólem } \\
\cline { 2 - 5 } & $\mathbf{K}$ & & $\mathbf{M}$ & & \\
\cline { 2 - 5 } & tak & nie & tak & nie & tak \\
\hline Przemoc w małżeństwie lub w rodzinie & 49,1 & 3,4 & 41,3 & 6,4 & 90,2 \\
\hline Niewierność & 27,5 & 24,8 & 27,3 & 20,4 & 54,8 \\
\hline Kłótnie, problemy nie do rozwiązania & 17,6 & 34,8 & 17,9 & 29,7 & 35,6 \\
\hline Uzależnienia partnera/partnerki & 19,3 & 33,0 & 12,8 & 35,0 & 32,1 \\
\hline Kiedy wygaśnie miłość & 10,9 & 41,4 & 10,7 & 37,0 & 21,6 \\
\hline Gdy partnerzy żyją oddzielnie & 5,7 & 46,7 & 4,7 & 42,9 & 10,4 \\
\hline $\begin{array}{l}\text { Nie wolno się rozwodzić, gdyby } \\
\text { to dotykało dzieci }\end{array}$ & 1,7 & 50,7 & 5,0 & 42,6 & 6,7 \\
\hline $\begin{array}{l}\text { Małżeństwo jest nierozerwalne, } \\
\text { jestem przeciw rozwodom }\end{array}$ & 2,3 & 50,1 & 2,6 & 45,0 & 4,9 \\
\hline Inne powody & 0,7 & 51,6 & 0,4 & 47,3 & 1,1 \\
\hline Powody finansowe & 0,1 & 52,3 & 0,8 & 46,8 & 0,9 \\
\hline Choroba partnera/partnerki & 0,3 & 52,1 & 0,3 & 47,3 & 0,6 \\
\hline
\end{tabular}

Analiza rozkładów statystycznych nie wykazała istotnych statystycznie zależności wyborów młodzieży w odniesieniu do przyczyn uzasadniających rozwód a uwarunkowaniami najczęściej tutaj wymienianymi. Można to interpretować jako przejaw zgodności u większości młodzieży na rozwód przy zaistnieniu wymienionych wyżej sytuacji w małżeństwie. 


\section{Znaczenie dzieci dla własnego planu życiowego}

Blisko $88 \%$ badanych jednoznacznie stwierdza, iż chce mieć dzieci, a tylko 2,2\% zdecydowanie nie wyraża takiej chęci. Z kolei $10 \%$ młodych ludzi jeszcze nie wie, czy chce mieć dzieci w przyszłości. (tab. 8). Dane te są podobne do uzyskanych w innych badaniach polskich (CBOS: 2000).

Tabela 8 . Plany prokreacyjne badanych a płeć $(w \%, N=2338)$

\begin{tabular}{|l|c|c|c|}
\hline \multirow{2}{*}{$\begin{array}{c}\text { Czy chcialbyś/chcialabyś mieć } \\
\text { dzieci }\end{array}$} & \multicolumn{2}{|c|}{ Pleć } & \multirow{2}{*}{ Razem } \\
\cline { 2 - 3 } & Kobiety & Mężczyźni & \\
\hline Tak & 88,8 & 86,7 & 87,8 \\
\hline Nie & 2,0 & 2,4 & 2,2 \\
\hline Jeszcze nie wiem & 9,2 & 10,9 & 10,0 \\
\hline Razem & 52,4 & 47,7 & 100,0 \\
\hline
\end{tabular}

Istnieje silna zależność między postawą prokreacyjną respondentów a ich religijnością - im wyższa ocena własnej religijności, tym więcej osób deklaruje chęć posiadania dzieci $\left(\chi^{2}=119,45 ; d f=10 ; p=0,00\right)$. Życzenie to zgłasza o ponad $22 \%$ więcej osób określających się jako bardzo religijne niż deklarujących brak religijności (por. Adamski 2002: 197).

Istnieje zależność między planami prokreacyjnymi a pozytywną oceną związku rodziców: im lepiej postrzegane są relacje między rodzicami, tym więcej osób wyraża chęć posiadania dzieci $\left(\chi^{2}=29,93 ; d f=10 ; p=0,00\right)$. Można założyć, że pozytywne wzory stosunków między rodzicami sprzyjają budowaniu postaw prokreacyjnych młodzieży. Doświadczenia wyniesione ze swoich rodzin pochodzenia są (lub moga być) istotnym czynnikiem prorodzinnych orientacji życiowych młodych ludzi.

Tabela 9. Planowana liczba dzieci ( $w \%, N=2351)$

\begin{tabular}{|l|c|}
\hline Liczba dzieci & $\mathbf{\%}$ \\
\hline Jedno & 4,8 \\
\hline Dwoje & 55,7 \\
\hline Troje & 21,2 \\
\hline Czworo & 4,0 \\
\hline Pięcioro & 1,2 \\
\hline Brak odp. & 13,2 \\
\hline Razem & 100,0 \\
\hline
\end{tabular}


Na chęć posiadania dwojga dzieci wskazało $55,7 \%$ badanej młodzieży, a co piąty badany chciałby mieć troje dzieci (por. CBOS, 2000); 13,2\% nie udzieliło odpowiedzi na to pytanie.

Postawy prokreacyjne badanej młodzieży wykraczają poza aktualne tendencje demograficzne w Polsce. Gdyby zostały zrealizowane, współczynnik dzietności wyniósłby dla badanej tutaj grupy kobiet 2,07 i byłby zdecydowanie wyższy od obecnego. Zagwarantowałby on prostą zastępowalność pokoleń (co ma miejsce przy współczynniku dzietności na poziomie 2,10-2,15). Dodajmy, że współczynnik ten osiaggnięty został w Polsce po raz ostatni w 1988 roku (w 2004 wynosił 1,23) 3 .

Chcąc dowiedzieć się, jakie znaczenie mają dzieci w planach na przyszłość postawiono młodzieży kilka pytań. W jednym $\mathrm{z}$ nich („Jakie znaczenie - w Twoich planach na przyszłość - mają dzieci?") poproszono badanych, aby zaznaczyli swój stosunek do tej kwestii w skali od 1 do 6 , gdzie „1” oznaczało „One nie mają dla mnie żadnego znaczenia” a „6” - „One mają dla mnie bardzo duże znaczenie”4. Wyniki przedstawia tabela 10 :

Tabela 10. Znaczenie dzieci w planach na przyszłość (w \%, N=2351)

\begin{tabular}{|c|c|c|c|c|c|c|}
\hline $\mathbf{\%}$ & 1,2 & 2,2 & 3,9 & 10,2 & 27,5 & 45,4 \\
\hline Ranga & $\mathbf{1}$ & $\mathbf{2}$ & $\mathbf{3}$ & $\mathbf{4}$ & $\mathbf{5}$ & $\mathbf{6}$ \\
\hline
\end{tabular}

Zdecydowana większość młodzieży udzieliła odpowiedzi na to pytanie - 90,3\% (9,4\% nie potrafiło określić swojego stanowiska). Około $83 \%$ badanych ulokowało swoje oceny w prawej części skali uznając, że w ich planach na przyszłość dzieci będą odgrywać dużą rolę $(x=5,18)$. Wzmacnia to wcześniejsze stwierdzenie o prorodzinnej orientacji życiowej młodych Polaków. Przy czym kobiety $(52,6 \%)$ zdecydowanie częściej od mężczyzn (37,7\%) wskazywały na kategorię „6” (bardzo duże znaczenie). Odpowiedzi silnie różnicują ocena własnej religijności i ocena związku rodziców. W obu przypadkach mamy do czynienia z zależnościami statystycznie istotnymi:

- im wyższa ocena własnej religijności, tym większe znaczenie dzieci w planach życiowych młodzieży - 93,7\% osób, określających się jako bardzo religijne (ranga „6”), przyznaje bardzo duże znaczenie dzieciom w swoich planach życiowych: ranga , 5 " i , $6 "\left(\chi^{2}=276,55 ; d f=25 ; p=0,00 ; r h o=0,29\right)$;

- im wyższa ocena relacji między rodzicami, tym większe znaczenie dzieci w planach życiowych młodzieży; 89,1\% osób, które najwyżej oceniają relacje między swoimi rodzicami (ranga „6”), przypisują potomstwu duże znaczenie (ranga „5” $\mathrm{i},, 6 ”)\left(\chi^{2}=119,28 ; d f=30 ; p=0,00 ;\right.$ rho $\left.=0,21\right)$.

Potwierdzeniem powyższych stwierdzeń są odpowiedzi na inne pytanie, w którym poproszono badanych o ocenę wagi (w skali od 1 do 6) określonych wartości, zasad i celów życiowych w perspektywie przyszłości (pyt. 61. „Co będzie ważne za 25 lat?”). Aż 80,6\% respondentów uważa, że posiadanie dzieci będzie miało dla 
nich duże znaczenie w przyszłości (ranga „5” i „6”), co potwierdza wiarygodność wcześniej złożonych deklaracji.

Jakie są motywy posiadania dzieci? Najczęściej badani zwracają uwagę na wzbogacający życie kontakt z dzieckiem (tab. 11): dzieci nadają sens życiu (42,0\%) i wzbogacają życie (30,0\%).

Tabela 11. Motywy posiadania dzieci

\begin{tabular}{|l|c|}
\hline \multicolumn{1}{|c|}{ Dlaczego chciałbyś/chciałabyś mieć dzieci? } & $\mathbf{\%}$ \\
\hline Ponieważ nadaje to sens mojemu życiu & 41,98 \\
\hline Ponieważ dzieci sprawiają iż rodzina jest prawdziwa & 31,60 \\
\hline Ponieważ dzieci wzbogacają moje życie & 30,03 \\
\hline Ponieważ dzieci wzmacniają więź między rodzicami & 18,63 \\
\hline Chcę mieć dzieci, aby być potrzebnym & 14,38 \\
\hline
\end{tabular}

Płeć w sposób statystycznie istotny różnicuje wybór wyżej wymienionych motywów posiadania dzieci: ,"ponieważ nadaje to sens mojemu życiu” $\left(\chi^{2}=10,76 ; d f=1\right.$; $p=0,001)$, „ponieważ dzieci wzbogacają moje życie” $\left(\chi^{2}=17,42 ; d f=1 ; p=0,00\right)$. W obu przypadkach częściej na nie wskazywały kobiety. Także wraz z rosnącą religijnością rośnie odsetek osób je wskazujących $\left(\chi^{2}=64,07 ; d f=5 ; p=0,00\right)$. Upoważnia to do stwierdzenia, że religijne motywy wzmacniają postawę prokreacyjną znacznej części badanej młodzieży.

Nieliczni respondenci, którzy nie chcą mieć dzieci (tylko 47 osób - 2,22\%), swoją postawę usprawiedliwiają brakiem umiejętności w pełnieniu roli ojca lub matki (skąd mogą to wiedzieć nie mając dzieci?).

Jakie warunki-zdaniem młodzieży - są niezbędne, by założyć rodzinę (posiadać dzieci)? Z niewiadomych powodów tylko niewielka liczba respondentów odpowiedziała na to pytanie. Cztery najczęściej wybierane warunki prezentuje tab. 12.

Tabela 12. Warunki niezbędne do posiadania dzieci (w \%)

\begin{tabular}{|l|c|c|}
\hline \multicolumn{1}{|c|}{ Kategoria odpowiedzi } & $\mathbf{\%}$ & Ranga \\
\hline Kiedy jest się niezależnym finansowo & 8,25 & I \\
\hline W przypadku, gdy chcą tego oboje partnerzy & 6,34 & II \\
\hline Kiedy posiada się stałe miejsce pracy & 5,27 & III \\
\hline Kiedy posiada się własny dom & 4,25 & IV \\
\hline
\end{tabular}

Odpowiedzi wskazują na poczucie odpowiedzialności za warunki, jakie rodzice powinni stwarzać dla rozwoju dziecka. Można jedynie zastanawiać się, o jaki poziom niezależności finansowej chodzi respondentom, mając na uwadze niepokojące dziś 
tendencje odraczania poczęcia dziecka na rzecz kariery zawodowej i osiaggania określonego statusu materialnego i społecznego.

O postawie wobec dzieci mówi także stosunek do aborcji (tab. 13). Zdecydowanie praktykę tę odrzuca $27,9 \%$ badanych, zaś $69,1 \%$ ją dopuszcza. To stanowisko istotnie różnicuje ocena własnej religijności: wraz z jej wzrostem maleje przyzwolenie na aborcję $\left(\chi^{2}=443,95 ; d f=24 ; p=0,00 ; C=0,40\right)$. Warto jednak zauważyć, że ponad połowa $(53,0 \%)$ spośród tych, którzy określają się jako osoby religijne (ranga „5" i „6") dopuszcza możliwość usunięcia ciąży zarówno z tzw. ważnych powodów (ciąża z gwałtu, choroba matki, niedostateczna sytuacja materialna), a także aborcji „na życzenie”. Można więc mówić tu o pewnym pragmatyzmie etycznym młodych Polaków i liberalizacji wartości dziecka, które są związane z rozluźnianiem norm religijnych młodzieży.

Tabela 13. Opinie badanych na temat aborcji a płeć (w \%, N=2344)

\begin{tabular}{|l|c|c|c|}
\hline \multirow{2}{*}{\multicolumn{1}{|c|}{ Co sądzisz na temat aborcji? }} & \multicolumn{2}{c|}{ Pleć } & \multirow{2}{*}{ Razem } \\
\cline { 2 - 3 } & K & M & \\
\hline Jestem zasadniczo przeciwny aborcji & 28,8 & 26,9 & 27,9 \\
\hline $\begin{array}{l}\text { Są wyjątkowe sytuacje, w których uważam } \\
\text { aborcję za dopuszczalną (gwałt, choroba matki) }\end{array}$ & 58,0 & 55,7 & 56,9 \\
\hline $\begin{array}{l}\text { Jestem za aborcją, gdy sytuacja materialna } \\
\text { nie zezwala na posiadanie dziecka }\end{array}$ & 4,2 & 6,1 & 5,1 \\
\hline Jestem całkowicie za aborcją & 6,8 & 7,4 & 7,1 \\
\hline Nie wiem & 2,2 & 3,9 & 3,0 \\
\hline Razem & 52,4 & 47,6 & 100,0 \\
\hline
\end{tabular}

Dwa kolejne analizowane tu pytania pozwalają zweryfikować zgłaszane wcześniej opinie na temat znaczenia posiadania dzieci w życiu osobistym. Respondentów pytano o to, czy posiadanie dzieci uszczęśliwia człowieka: pierwsze z pytań dotyczyło kobiety, drugie mężczyzny.

Tabela 14. Posiadanie dziecka źródłem szczęścia kobiety a płeć (w \%; N=2345)

\begin{tabular}{|l|c|c|c|}
\hline \multirow{2}{*}{$\begin{array}{c}\text { Jaka kobieta będzie według Ciebie ogólnie } \\
\text { szczęśliwsza: kobieta z dziećmi czy kobieta bez dzieci? }\end{array}$} & \multicolumn{2}{|c|}{ Płeć } & \multirow{2}{*}{ Razem } \\
\hline Kobieta z dziećmi & 47,0 & 50,2 & 48,5 \\
\hline Kobieta bez dzieci & 0,4 & 1,7 & 1,0 \\
\hline $\begin{array}{l}\text { Szczéście kobiety nie jest uzależnione } \\
\text { od posiadania dzieci }\end{array}$ & 45,5 & 36,7 & 41,3 \\
\hline Nie wiem & 7,1 & 11,5 & 9,2 \\
\hline Razem & 52,3 & 47,7 & 100,0 \\
\hline
\end{tabular}


Tabela 15. Posiadanie dziecka źródłem szczęścia mężczyzny a płeć (w \%; N=2342)

\begin{tabular}{|l|c|c|c|}
\hline \multirow{2}{*}{$\begin{array}{l}\text { Który mężczyzna będzie według Ciebie } \\
\text { ogólnie szczęśliwszy: mężczyzna z dziećmi czy } \\
\text { mężczyzna bez dzieci? }\end{array}$} & \multicolumn{2}{|c|}{ Płeć } & \multirow{2}{*}{ Razem } \\
\cline { 2 - 3 } & K & M & \\
\hline Mężczyzna z dziećmi & 32,6 & 42,2 & 37,2 \\
\hline Mężczyzna bez dzieci & 3,6 & 4,7 & 4,1 \\
\hline $\begin{array}{l}\text { Szczęście mężczyzny nie jest uzależnione od } \\
\text { posiadania dzieci }\end{array}$ & 49,4 & 42,2 & 46,0 \\
\hline Nie wiem & 14,4 & 11,0 & 12,8 \\
\hline Razem & 52,4 & 47,6 & 100,0 \\
\hline
\end{tabular}

Prawie połowa badanych $(48,5 \%)$ uznaje, iż szczęśliwsza będzie kobieta posiadająca dzieci, choć spora część $(41,3 \%)$ nie wiąże faktu posiadania dzieci ze szczęściem. Mężczyźni są bardziej skłonni wiązać szczęście kobiet z dziećmi, natomiast kobiety częściej mówią o braku takiego związku $\left(\chi^{2}=33,84 ; d f=3 ; p=0,00\right)$. Występuje też bardzo silne zróżnicowanie odpowiedzi ze względu na ocenę własnej religijności przez badanych. Mamy tutaj do czynienia z istotną zależnością statystyczną $\left(\chi^{2}=79,30 ; d f=18 ; p=0,00\right)$, którą można określić w następujący sposób: religijność młodzieży pozostaje w ścisłym związku z bardziej tradycyjnym systemem wartości i przekonań. Analiza danych wskazuje, że mężczyźni bardziej tradycyjnie postrzegają role mężczyzny i kobiety w rodzinie, a także prezentują bardziej zachowawczy system wartości. Zdecydowanie częściej wiążą fakt szczęścia osobistego z posiadaniem dziecka, opinie takie zgłaszając zarówno w odniesieniu do kobiet, jak i mężczyzn.

\section{Podział ról w rodzinie oraz w związku partnerskim}

Role małżeńskie są ważnym elementem systemu rodziny (por. Przybył 1977: 81-95). Wpływają one na kształt relacji małżeńskich i rodzicielskich, jakość stosunków między samymi małżonkami oraz rodzicami i dziećmi (Rostowski 1987: 115 i nast.). W przechodzeniu od tradycyjnego do nowoczesnego modelu rodziny proces przejmowania i kształtowania ról nie jest wolny od różnorodnych napięć i konfliktów (por. Biernat 2005: 29-45). Interesujące jest, w jaki sposób badana młodzież wyobraża sobie swoją przyszłą rodzinę w aspekcie ról małżeńskich. Zdecydowana większość badanej młodzieży preferuje partnerski układ ról małżeńskich. Prawie trzy czwarte badanych (72,6\%) wyraziło opinię, że najchętniej by żyło w rodzinie, w której małżonkowie pracują zawodowo i razem dzielą obowiązki zawodowe i wychowawcze. Za rodzina, w której kobieta zajmuje się domem i pracuje w niepełnym wymiarze godzin opowiedziało się 17,4\%. Tylko 6\% badanych preferowało rodzinę, w której mąż pracuje, a kobieta zajmuje się domem i dziećmi. Sytuacja z pracującą żoną i mężem pozostającym w domu prawie w ogóle nie była brana pod uwagę $(0,6 \%)$. 
Tabela 16. Podział ról w rodzinie a płeć $(\mathrm{w} \%, \mathrm{~N}=2341)$

\begin{tabular}{|l|c|c|}
\hline \multicolumn{1}{|c|}{ Podzial ról w rodzinie } & K & M \\
\hline $\begin{array}{l}\text { Rodzina, w której tylko mężzyzna pracuje zawodowo, a kobieta } \\
\text { zajmuje się gospodarstwem domowym i wychowuje dzieci }\end{array}$ & 2,8 & 9,8 \\
\hline $\begin{array}{l}\text { Rodzina, w której tylko kobieta pracuje zawodowo, a mężczyzna } \\
\text { zajmuje się gospodarstwem domowym i wychowuje dzieci }\end{array}$ & 0,1 & 1,3 \\
\hline $\begin{array}{l}\text { Rodzina, w której oboje małżonkowie/partnerzy mają zawód } \\
\text { i oboje na równi dzielą obowiązki domowe i wychowawcze }\end{array}$ & 80,6 & 64,4 \\
\hline $\begin{array}{l}\text { Rodzina, w której oboje małżonkowie/partnerzy pracują zawodowo, } \\
\text { ale mężczyzna mniej pracuje niż kobieta i bierze na siebie więcej } \\
\text { obowiązków domowych }\end{array}$ & 0,9 & 1,8 \\
\hline $\begin{array}{l}\text { Rodzina, w której oboje małżonkowie/partnerzy pracują zawodowo, } \\
\text { ale kobieta mniej pracuje niż mężczyzna i bierze na siebie więcej } \\
\text { obowiązków domowych }\end{array}$ & 14,9 & 20,4 \\
\hline Nie mam rodziny, lecz żyję w pojedynkę, niezależnie & 0,7 & 1,8 \\
\hline W innej formie & 0,1 & 0,5 \\
\hline
\end{tabular}

I w tym przypadku opinie mężczyzn wydają się być nieco bardziej tradycyjne niż kobiet $\left(\chi^{2}=104,91 ; d f=6 ; p=0,00\right)$. Za rodzina, w której tylko mąż pracuje zawodowo, a żona zajmuje się domem i dziećmi opowiedziało się 2,8\% kobiet i 9,8\% mężczyzn. Kobiety częściej były za partnerskim podziałem ról niż mężczyźni. Za równym rozłożeniem obowiązków zawodowych i rodzinnych między małżonków opowiedziało się $80,6 \%$ kobiet i 64,4\% mężczyzn. Mężczyźni preferują taką sytuację, w której żona pracuje w mniejszym wymiarze czasowym, co pozwala jej realizować się w domu i w pracy zawodowej. Taki punkt widzenia ujawniło 14,9\% kobiet i 20,4\% mężczyzn. Odwrotny podział ról zyskał znikomą aprobatę badanych. Układ rodzinny, w którym żona pracuje zawodowo, a mąż (pracujący także na część etatu) zajmuje się domem wybrało jedynie 1-2\% badanych osób. Za takim podziałem ról w rodzinie, gdzie mąż pracuje a żona prowadzi dom i wychowuje dzieci, opowiedziało się $8,4 \%$ badanych, których ojcowie legitymują się wykształceniem podstawowym i 3,6\% badanych, których ojcowie mają wykształcenie wyższe magisterskie $\left(\chi^{2}=67,16 ; d f=30 ; p=0,000\right)$. Respondenci, których matki nie pracują, częściej wyrażali pogląd, że to mąż powinien utrzymywać rodzinę, a matka zajmować się domem (11,9\%). Taką samą opinię wyraziło 4,8\% badanych, których matki pracują zawodowo. Partnerski podział ról nieco częściej preferują respondenci matek pracujących $(72,8 \%)$ niż przebywających w domu $(67,3 \%)$, choć różnice te nie są duże $\left(\chi^{2}=53,97 ; d f=30 ; p=0,004\right)$.

We współczesnym modelu rodziny, który jest nazywany modelem partnerskim, mąż i żona dzielą się różnymi pracami w gospodarstwie domowym. Podział zadań nie jest symetryczny, ale taki, który uwzględnia indywidualne potrzeby i oczekiwa- 
nia małżonków, co jest wynikiem obopólnego poszukiwania rozwiązań satysfakcjonujących obie strony (Dyczewski 1999: 103-132).

Opinie na temat podziału zadań w domu między małżonkami (tab. 17) pokazują, że w świadomości badanych funkcjonuje podział zadań na typowo męskie i typowo żeńskie prace (choć istnieją także takie, które mąż i żona wykonują wspólnie). Ogólnie można powiedzieć, że zdaniem młodzieży większość prac małżonkowie powinni wykonywać wspólnie i do takich zaliczają opiekę nad chorymi rodzicami i dziećmi, opiekę nad dziećmi. Jednak prace domowe przypisane są częściej kobiecie. Na niej głównie spoczywają takie obowiązki jak: pranie, gotowanie, sprzątanie mieszkania, robienie zakupów. Do tradycyjnie męskich prac badani zaliczyli naprawy i remonty w domu. Można stwierdzić ogólnie, iż - mimo tendencji do demokratycznego podziału zadan - to mężczyzna zajmuje bardziej uprzywilejowaną pozycję w małżeństwie.

Tabela 17. Opinie na temat podziału zadań w małżeństwie

\begin{tabular}{|l|c|c|c|c|c|}
\hline \multirow{2}{*}{\multicolumn{1}{|c|}{ Rodzaj zadania }} & \multicolumn{5}{c|}{ Wyraźnie jest to: } \\
\cline { 2 - 6 } & zadanie kobiety & \multicolumn{3}{c|}{ zadanie mężczyzny } \\
\hline 1. Sprzątanie mieszkania & $\mathbf{5}$ & $\mathbf{4}$ & $\mathbf{3}$ & $\mathbf{2}$ & $\mathbf{1}$ \\
\hline 2. Pranie & 24,1 & 20,0 & 64,7 & 0,7 & 0,6 \\
\hline 3. Małe naprawy i remonty w domu & 1,1 & 1,1 & 11,0 & 31,5 & 54,7 \\
\hline 4. Opieka nad chorymi dziećmi & 6,8 & 13,4 & 78,4 & 0,4 & 0,5 \\
\hline 5. Opieka nad chorymi rodzicami & 3,4 & 7,3 & 87,3 & 0,7 & 0,5 \\
\hline 6. Robienie zakupów & 7,9 & 20,3 & 67,1 & 3,0 & 1,4 \\
\hline 7. Gotowanie & 15,9 & 32,3 & 48,1 & 2,5 & 0,9 \\
\hline 8. Praca w ogrodzie & 5,7 & 13,3 & 61,3 & 13,2 & 5,5 \\
\hline 9. Opieka nad dziećmi & 4,7 & 10,5 & 83,9 & 0,3 & 0,3 \\
\hline
\end{tabular}

Średnie dla poszczególnych kategorii: $1-3,45 ; 2-3,83 ; 3-1,61 ; 4-3,25 ; 5-3,12 ; 6-3,30 ; 7-3,59$; 8-3,0; 9-3,19.

Z porównania opinii na temat tego, jak powinien wyglądać podział zadań między małżonkami i jaki jest w rodzinach badanej młodzieży wynika, że wyobrażenia odbiegają od realiów życia. Postulaty dotyczące podziału obowiązków domowych (tab. 17) są bardziej demokratyczne niż faktyczny podział prac w domach (tab. 18). Wyniki ujawniły dość duże obciążenie matek domowymi pracami. To one wykonują większość prac związanych z utrzymaniem domu. Do mężczyzn należą naprawy i remonty. Funkcjonujący układ ról oraz związany z nimi podział obowiązków odzwierciedla raczej tradycyjny model rodziny. Niesymetryczny podział pracy w domu wskazuje na istnienie uprzywilejowanej pozycji mężczyzny w polskich domach. 
Obciążenie pracą zawodową matek i ojców jest podobna (aktywnych zawodowo było $58 \%$ matek i $67 \%$ ojców), ale podział prac i obowiązków w domach nierówny, na niekorzyść kobiet.

\begin{tabular}{|c|c|c|c|c|c|c|c|c|c|}
\hline 元 & $\stackrel{\infty}{\varrho}$ & $\hat{a}$ & $\hat{\overbrace{}}^{2}$ & $\stackrel{\nabla_{n}}{\vec{N}}$ & $\stackrel{+}{\stackrel{\nabla}{d}}$ & $\begin{array}{l}n \\
\tilde{\nu} \\
\tilde{\nu}\end{array}$ & $\vec{\overbrace{}}$ & $\begin{array}{l}n \\
\hat{N}\end{array}$ & 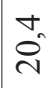 \\
\hline 䄈 & $\stackrel{a}{n}$ & $\stackrel{n}{\sim}$ & $\overrightarrow{6}$ & $\cong$ & $\begin{array}{l}\infty \\
\forall\end{array}$ & 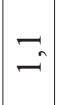 & $\stackrel{2}{-}$ & $\vec{n}$ & $\begin{array}{l}0 \\
0\end{array}$ \\
\hline 芯 & గ్ & $\overrightarrow{0}$ & $\stackrel{\infty}{\circ}$ & గ్ & $\sigma_{0}^{+}$ & ָ̃ & $\tilde{\sigma}^{\prime}$ & $\begin{array}{l}\nabla_{0} \\
\text { nis }\end{array}$ & $\overrightarrow{0}$ \\
\hline 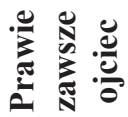 & $\stackrel{?}{\sim}$ & $\hat{\sigma}$ & ๙n & $\mathfrak{o}^{n}$ & $\hat{\sigma}^{\circ}$ & $\begin{array}{l}m \\
n\end{array}$ & $\hat{\sigma}$ & 0 & గn \\
\hline 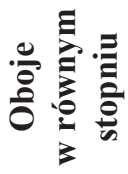 & $\stackrel{n}{\sim}$ & $\stackrel{n}{\nabla}$ & $n$ & $\begin{array}{l}\hat{n} \\
\tilde{m}\end{array}$ & $\stackrel{\tilde{g}}{\sigma}$ & $\begin{array}{l}\text { No } \\
\tilde{D}^{\prime}\end{array}$ & $\stackrel{\sim}{ \pm}$ & $\frac{0}{m}$ & $\begin{array}{l}0 \\
i n\end{array}$ \\
\hline • & $\frac{\sigma_{n}}{m}$ & $\stackrel{m}{\tilde{v}}$ & $\stackrel{\nabla}{\sigma}$ & $\begin{array}{l}0 \\
\stackrel{0}{0} \\
\stackrel{2}{0}\end{array}$ & $\stackrel{\sim}{ \pm}$ & $\begin{array}{l}0 \\
\hat{2}\end{array}$ & $\stackrel{a}{\sim}$ & $\hat{\sigma}^{\circ}$ & $\stackrel{\nabla}{\sigma}$ \\
\hline 趂 & $\begin{array}{l}0 \\
\text { ర) }\end{array}$ & qn & $\hat{\sigma}$ & సి & $\stackrel{\infty}{\sim}$ & $\hat{n}$ & $\hat{n}$ & $\begin{array}{l}0 \\
0 \\
0\end{array}$ & $\begin{array}{l}\nabla_{0} \\
\pm\end{array}$ \\
\hline 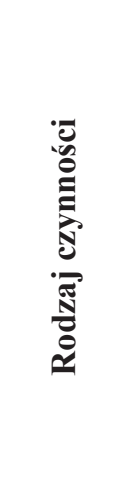 & 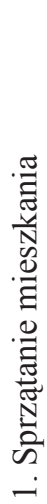 & 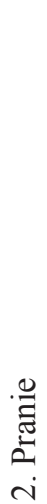 & 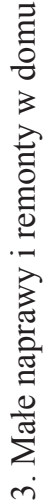 & 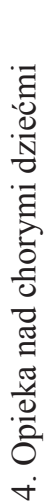 & 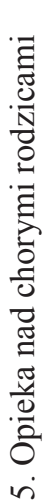 & 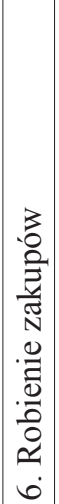 & $\begin{array}{l}0 \\
0 \\
0 \\
3 \\
0 \\
0 \\
0 \\
0 \\
ن\end{array}$ & $\mid \begin{array}{c}0 \\
0 \\
0 \\
0 \\
0 \\
0 \\
0 \\
3 \\
0 \\
0 \\
0 \\
\tilde{T} \\
0 \\
\infty \\
\infty\end{array}$ & 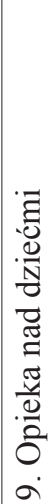 \\
\hline
\end{tabular}


Ważną kwestią, która pojawia się po urodzeniu dziecka jest pogodzenie z obowiązkami rodzicielskimi pracy zawodowej. Ta sytuacja często wymaga podjęcia decyzji o przerwaniu pracy jednego z rodziców. W Polsce urlop wychowawczy może wziąć zarówno kobieta, jak i mężczyzna. Badana młodzież preferuje dwa rozwiązania: matka bierze urlop wychowawczy i opiekuje się dzieckiem $(41,1 \%)$ lub matka i ojciec dzielą urlop wychowawczy między siebie $(38,4 \%)$. Na trzecim miejscu uplasowało się rozwiązanie, w którym obydwoje rodzice pracują zawodowo, a dzieckiem - w miarę możliwości - zajmują się dziadkowie $(12,4 \%)$.

Rozkłady powyższych deklaracji różnicuje religijność $\left(\chi^{2}=65,68 ; d f=36 ; p=0,001\right)$. Osoby wyżej ceniące swoją religijność są bardziej skłonne powierzyć opiekę nad dzieckiem matce $\left(\chi^{2}=65,68 ; d f=36 ; p=0,001\right)$. Podobne myślą młodsi badani, którzy wydają się mieć bardziej tradycyjne nastawienie, niż starsi: 44,3\% młodzieży do 20 roku życia uważa, że matka powinna zostać w domu i zając się dzieckiem (21 lat i powyżej $\left.-37,3 \% ; \chi^{2}=30,67 ; d f=6 ; \mathrm{p}=0,000\right)$.

\section{Wnioski ogólne}

1. Podstawową i upragnioną formą życia rodzinnego dla młodzieży jest małżeństwo posiadające przynajmniej jedno dziecko. Taka też forma życia rodzinnego dominuje w polskim społeczeństwie. Według ostatniego spisu powszechnego w roku 2002 małżeństwa z dziećmi stanowiły 56,0\% wśród ogólnej liczby rodzin 10.457.617 rodzin (Narodowy Spis 2003: 27, 41).

2. Młodzież ceniąc sobie życie małżeńsko-rodzinne, uważa, że małżeństwo i rodzina mają charakter wspólnotowy i instytucjonalny jednocześnie. Traktują je jako instytucje odrębne, lecz ściśle z sobą powiązane, a także jako instytucje względnie trwałe. Opowiadając się za trwałością małżeństwa, większość badanych dopuszcza rozwód w sytuacji, kiedy wzajemne relacje osobowe są stale utrudnione lub wręcz niemożliwe. Najczęściej wskazywanymi powodami do rozwiązania małżeństwa są: przemoc, niewierność, niedające się rozwiązać problemy i długotrwałe kłótnie, uzależnienia. Pomimo aprobaty rozwodów pod określonymi warunkami przez większość społeczeństwa, wskaźnik rozwodów w Polsce jest jednym z najmniejszych w Europie. W ostatnich latach wskazuje pewną tendencję wzrostową: w roku 2000 na tysiąc mieszkańców było 1,1 rozwodów, w roku 2004 - 1,5 (Mały Rocznik Statystyczny 2005: 120).

3. Młodzież bardzo wysoko ceni sobie posiadanie dzieci i najczęściej preferuje dwójkę dzieci we własnej rodzinie, następnie trójkę oraz większą liczbą dzieci (częściej niż jedno dziecko). Jej plany prokreacyjne, gdyby zostały zrealizowane, mogłyby pozytywnie wpłynąć na sytuację demograficzną w Polsce i zmienić niekorzystne wskaźniki demograficzne (Dyczewski 2005: 323-330).

4. Większość młodzieży opowiada się za dopuszczalnością aborcji z ważnych powodów. Zdecydowani obrońcy poczętego życia ludzkiego stanowią nieco więcej niż jedną czwartą badanej populacji (27,9\%). Jeżeli odsetek osób aprobujących aborcję, 
odniesiemy do respondentów, którzy są za małżeństwami homoseksualnymi $(22,8 \%)$, aprobują zrównanie małżeństw ze związkami nieformalnymi (36,2\%), odrzucającymi ślub kościelny (11,6\%), to możemy przyjąć, że około jedna czwarta młodzieży w zasadniczych sprawach małżeńsko-rodzinnych ma poglądy liberalne w stosunku do katolickiej moralności.

5. Na wyobrażenia młodzieży o małżeństwie i rodzinie najsilniejszy wpływ mają ocena osobistej religijności, ocena związku pomiędzy rodzicami i z rodzicami, płeć i wiek, a o wiele słabszy, i tylko na wybrane sprawy, sytuacja szkolna młodzieży, sytuacja zawodowa matki, poziom wykształcenia rodziców. Kierunek tych zależności na ogół jest taki, że im wyższa ocena religijności, związku rodziców i własnych relacji z rodzicami, tym większa akceptacja małżeństwa/rodziny z dzieckiem jako podstawowej formy życia rodzinnego. Słaba siła zależności pomiędzy wyobrażeniami młodzieży na małżeństwo i rodziny a takimi czynnikami społeczno-demograficznymi, jak wiek, płeć, praca zawodowa matek, wykształcenie, aktualne zajęcie, wskazuje na duże ujednolicenie poglądów na wiele spraw życia małżeńsko-rodzinnego w ramach tego samego pokolenia.

6. Nasze badania, jak i badania przeprowadzone przez inne ośrodki naukowo-badawcze wskazują, że zmienia się sama instytucja małżeństwa i rodziny w kierunku bardziej partnerskich relacji. Różnicują się poglądy na małżeństwo i rodzinę. W świadomości młodzieży istnieje otwartość na odmienne formy życia małżeńsko-rodzinnego oraz tolerancja wobec nowych postaw prorodzinnych i arodzinnych, które w ostatnim czasie coraz bardziej cechuje pluralizm i różnorodność. Zdecydowana większość młodzieży pragnie życia rodzinnego opartego na małżeństwie dwóch osób odmiennej płci z dziećmi, o demokratycznej strukturze i partnerskich relacjach.

\section{Bibliografia}

Adamski F. (2002), Rodzina. Wymiar społeczno-kulturowy, Kraków.

Biernat T. (2005), Youth's opinions concerning marriage (aged 18-24). Research announcement, w: Verscheidene Wege gemeinsame Ziele, Hrsg. H. Zielińska-Kostyło, Wydawnictwo Uniwersytetu Mikołaja Kopernika, Torun.

CBOS (2000), Sytuacja polskich rodzin - oceny i postulaty. Komunikat z badań, Warszawa, marzec CB/053/2000.

Dyczewski L. (2005), Familialer Wandel in Polen. In: Familie und Gesellschaft. Beiträge zur Familienforschung, Hrsg. F. W. Busch, R. Nave-Herz, BIS, Oldenburg.

Dyczewski L. (1999), The Family in a Transforming Society, The Learned Society of the Catholic University of Lublin, Lublin.

Giza-Poleszczuk A. (2002), Zwiazki partnerskie, małzenśstwo i dzieci - kulturowe zróżnicowanie postaw, w: Polacy wśród Europejczyków. Wartości spoleczeństwa polskiego na tle innych krajów europejskich, red. A. Jasińska-Kania, M. Marody, Wydawnictwo Naukowe Scholar, Warszawa.

Mały Rocznik Statystyczny (2005), GUS, Warszawa.

Narodowy Spis Powszechny ludności i mieszkań 2002. Gospodarstwa domowe i rodziny (2003), GUS, Warszawa. 
Przybył I. (1997), Role matżeńskie na tle wybranych ujęć teoretycznych, Roczniki Socjologii Rodziny, t. XI/1997.

Rostowski J. (1987), Zarys psychologii malżeństwa, Państwowe Wydawnictwo Naukowe, Warszawa.

Slany K. (2002), Alternatywne formy życia matżeńsko-rodzinnego w ponowoczesnym świecie, Zakład Wydawniczy „Nomos”, Kraków.

\section{Young Polish people's ideas of marriage (Summary)}

The article contains a fragment of a research report concerning young people's views on marriage and family. The research was conducted in the following 4 provinces: Mazowiecki, Pomorski, Lubelski, and Kujawsko-Pomorski; they were in the form of auditory questionnaires, and were carried out from November 2004 until January 2005. It dealt with youngsters aged 18-26 (2351 individual questionnaires).

The great majority of youngsters continue to consider marriage, as a formalised relationship, to have great value. Marriage ought to be built on mutual respect and toleration, emotional and sexual fidelity, and the ability of forgiveness. Agreeing on the value of marriage, the majority of respondents concede the instance of divorce when interpersonal relations are disfunctional. The most frequent reasons for divorce are: violence in the marriage and family, infidelity, irresolvible problems and arguments, and partners' addictions.

Over $80 \%$ of young people want to have children; mostly 2 or 3 (the realization of these plans would enable the basic replacement of generations). The majority of young people are in favour of permitting abortion for important reasons. Firm advocates of defending human life from conception make up around a quarter $(27,9 \%)$.

In the light of the research results we may state that the views on the institution of marriage and family are changing. On the one hand, there is a great respect for the value of marriage - the vast majority of young people desire family life based on the marital bond of 2 people of different sexes with children, being of a democratic structure and built on partnership relations. On the other hand, we see a tendency towards liberalizing these views and attitudes. This is embodied in the growing openness and toleration of different forms of marital and family forms such as informal and homosexual relationships. 